\title{
EXECUTIVE PRIVILEGE, PROFESSOR ROSENBLUM, AND THE HIGHER CRITICISIM
}

\author{
RAOUL BERGER*
}

Professor Victor Rosenblum's review ${ }^{\mathrm{I}}$ of my Executive Privilege: $A$ Constitutional $M y t h,{ }^{2}$ is an exercise in straddling which befogs the issue. At one and the same time he pays tribute to the "vitality and timelessness of Berger's contribution"3 and accepts United States $v$. Nixon ${ }^{4}$ without blinking, delicately circling the fact that Berger's "myth" charge is utterly imcompatible with Chief Justice Burger's discovery that a privilege for confidential communications is "imextricably rooted in separation of powers." On Burger's premise Berger's "timeless contribution" falls in shards. Not a word about the salvo of criticism that greeted the Burger opinion, ${ }^{6}$ though one might expect that a reviewer would welcone the opportunity to weigh that criticism against the book and the opinion.

Goethe, we are told, "demands from the artist, above all, professional reliability." It is even more crucial to scholarship; and a critic who would sit in judgment must be equally reliable. His encomiums notwithstanding, Rosenblun1 devotes the bulk of his pages to disparagement: Berger "pounds, mashes, grinds ... those . . . who have had the temerity to proclaim that executive privilege is not alien to the Constitution"; he "disputes allegedly conclusive 'precedents' of execu-

* Charles Warren Senior Fellow in American Legal History, Harvard University; A.B., University of Cincinnati, 1932; J.D., Northwestern University, 1935; L.L.M., Harvard University, 1938.

THE FOLIOWING CITATIONS WILL BE USED IN THIS ARTICLE:

R. Berger, Executive Privilege: A Constitutional Myth (1974) thereinafter cited as BERGER];

Cox, Executive Privilege, 122 U. PA. L. Rev. 1383 (1974) [hereinafter cited as Cox];

Rosenblum, Book Review, 69 Nw. U.L. Rev. 653 (1974) [hereinafter cited as Rosenbluin].

1. Rosenblum.

2. BERGER.

3. Rosenblum 653 .

4. 418 U.S. 683 (1974).

5. Id. at 708.

6. See Symposium: United States v. Nixon, 22 U.C.L.A.L. Rev. 1 (1974).

7. 3 A. Hauser, The Social Hrstory of ART 129 (Vintage ed.). 
tive privilege," etc., etc. ${ }^{8}$ In short, Berger writes as "advocate and adversary," and by implication his scholarship is not to be trusted. The scientific community has "one simple and devastating criterion, 'Is it true?" "10 Of the "precedents" Rosenblum himself states that "[i]n piercing the fatuous pretensions of proponents of absolutism, Berger has no peer. His verbal scythes cut away the nultiple cover-ups presidents have developed to justify suppression of information." 11 If that be true, ${ }^{12}$ it is of no inoment whether $I$ write as "advocate and adversary"; what matters is that I have proved my case.

Serious criticism demands that a reviewer come to grips with the central thesis of the writer. Nowhere does Rosenblun pause to appraise that thesis: namely, that the pre-1789 listory knows no such doctrine as executive privilege, and there is reason to believe that the Framers did not niean to create it. Such an appraisal is called for if only because of the inagnitude of the problem. An impeccable "nonadversary" scholar, Professor Archibald Cox, recently wrote that " $t$ t]he central problem today is low to deal with governmental secrecy and-to be blunt-with governmental deception. A congressional power to iniquire, freely exercised, could help to provide the necessary information."13 The citadel of the financial community came to a similar conclusion. " "Secrecy," said Professor Cox,

8. Rosenblum 654. Thus he devotes an entire page of his eight and one half pages to an ironical restatement of my refutation of Younger. Id. at 655-56.

9. Id. at 653 (an "adversary" who "stop[s] short of compiling an "enemies list" "). Against this background, his statement that "[d]espite the minor irritation evoked by Berger's yen for gladiatorial garb, Executive Privilege is a reinarkably thorough and instructive probe of presidential accountability . . . , id. at 654 , is not worth a fig.

Rosenblum expresses the hope that "confrontative scholarship should be diminished," id. at 660 , and cites as an example of "nonadversary scholarship that augur[s] a new scholastic attitnde . . . D. Frohnmayer, An Essay on Executive Privilege," winner of the ABA annual prize competition. Id. at 660 n.22. Frobnmayer's excellent synthesis leans heavily on my materials and liberally sprinkles citations to my book. Frohnmayer, An Essay on Executive Privilege, in Essays on EXecutrve PrTvilege (1974).

10. J. Sullivan, The LimTs ol? SCIENCe 174 (1932).

11. Rosenblum 658.

12. Professors Archibald Cox, A. Sofaer, and Garry Wills found my refutation of the "precedents" "devastating." Cox 1384 n.2; Sofaer, Book Review, 88 HARV. L. REv. 281, 288 (1974); Wills, Book Review, N.Y. Times, May 5, 1974, Book Rev. Sec., at 1 , col. 1. For a telling and more recent reduction of these "precedents" see Cox 13961405.

13. Cox 1434. Professor Rosenblnm acknowledges that in the 1970's the claims of privilege had become an "iron curtain which slut off crucial information from Congress and the people.'" Rosenblum 653 (citation omitted).

14. The "pattern of the past several decades strongly suggests that the theoretical dangers of government-by-fishbowl are greatly outweighed by the actual fact of excessive secrecy." Wall Street J., Nov. 20, 1974, at 26, col. 2. 
if sanctified by a plausible claim of constitutional privilege, is the easiest solution to a variety of problems. The claim of privilege is a useful way of hiding inefficiency, maladministration, breach of trust or corruption, and also a variety of potentially controversial executive practices not authorized by Congress. 15

That such practices have increasingly permeated the Executive branch I showed back in $1965 .^{16}$ Given the dimensions of executive secrecy, of its threat to our democratic society, it is of the utmost importance to establish whether or not the claimed privilege has any constitutional footing. Rosenblum's review obscures and beclouds my demonstration that it has none.

It will help the reader to have before him a compact summary of the historical data which led me to conclude that executive privilege has no constitutional warrant. Looking to the parhamentary practice at the adoption of the Constitution, the Supreme Court held in 1927 that "the power of inquiry . . . was regarded and employed as a necessary and appropriate attribute" of the legislative power and was conferred on Congress. ${ }^{17}$ Parliamentary records disclose that inquiry covered the entire spectruin of executive conduct. ${ }^{18}$ In the 1742 Parhament the great William Pitt summarized the practice: "We are called the Grand Inquest of the Nation, and as such it is our Duty to inquire into every Step of publick Management . . . in order to see that nothing has been done amiss . . . " With one explicable exception in $1742,{ }^{20} \mathrm{I}$ found no executive refusal to turn over information between 1621 and 1742. In 1701, Charles Davenant stated that "no one has ever questioned the legislative authority 'to enquire into, and correct the Errors and Abuses committed" "by those who exercised executive power. ${ }^{21}$ That was confirmed 130 years later by the Enghish historian,

15. $\operatorname{Cox} 1433$.

16. See generally Berger, Executive Privilege v. Congressional Inquiry (pts. 1 \& 2), 12 U.C.L.A.L. REv. 1044, 1287 (1965).

17. McGrain v. Daugherty, 273 U.S. 135, 175 (1927); see id. at 161.

18. BERGER 15-31.

19. 13 R. Chandler, History and Proceedings of Parliament from 1621 to the PRESENT 172-73 (1743), quoted in BERGER 29.

20. John Scropes, Secretary of the Treasury, refused to reveal Secret Service expenses. Parhament was stymied because Scropes, who was eighty years old, said he was perfectly willing to spend his remaining months in the Tower, and because he was indispensable to the operation of the Treasury and could not be spared for incarceration. A more dispensable official was jailed for refusing to discuss the same expenditures. BERGER 28-29, 170.

21. Bestor, Separation of Powers in the Domain of Foreign Affairs: The Original Intent of the Constitution Historically Examined, 5 SETON HALI L. REv. 527, 558 (1974), quoting C. Davenant, Essays upon I. The Barlance of Power. II. The Right of Making War, Peace, and Alliances. III. Universal Monarchy 207-08 (1701). 
Henry Hallam. ${ }^{22}$ How is this affected by the separation of powers? Not at all.

In quick summary, here is the historical proof:

1) Montesquieu, the Founders' oracle on the separation of powers, said that the legislature "has a right, and ought to have the means of examining in what manner its laws have been executed," in which the English, he added, enjoyed an advantage over some governments where public officers "gave no account of their administration.."23 2) James Wilson extolled the House of Commons, the Grand Inquest of the Nation, because it "checked the progress of arbitrary power . . . . The proudest ministers of the proudest monarchs . . . have appeared at the bar of the house to give an account of their conduct . . . ."24 3) References to the House as the "Grand Inquest of the Nation" are sprinkled through the records of the several Conventions; ${ }^{25}$ but in no case was protest made that this power was too broad or had to be curtailed for the protection of the Executive. The reason, I consider, is that in the Revolutionary period, to borrow from Bernard Bailyn, "faith ran high that a better world . . . could be built where authority was distrusted and held in constant scrutimy." 6 4) Given the recognized English practice, we may say witl Chief Justice Marshall, "[i] $t$ would . . . be expected that an opinion which is to overrule all former precedents, and to establish a principle never before recognized, should be expressed in plain and explicit terms."2t 5) Confirmation of the foregoing analysis is furmished by the Act of July 31,1789 , which iniposed upon the Secretary of the Treasury "the duty . . . to ... give information [to Congress] ... respecting all matters . . . which shall appertain to his office."28 Are we to conclude that this Act, drafted by Hamilton, co-author of The Federalist, enacted by the First Congress in which sat numerous Framers and Ratifiers, signed by President Washington, who had presided over the Conven-

22. 3 H. HALLAM, CONSTTIUTIONAL HisToRY OF ENGLAND 143 (1908).

23. 1 C. Montesquieu, The SpIRT of the LAws 187 (Philadelphia 1802).

24. 2 THE Works of JAMES WILSON 731 (McCloskey ed. 1967).

25. See BERGER 35.

26. B. Bailyn, The Ideological Origins of the Constitution 319 (1967). This is confirmed by James Wilson's statement in the Pennsylvania Ratification Convention: "The executive power is better to be trusted when it has no screen. . . . [The president cannot] hide either his negligence or inattention." 2 Debates IN THE SEveral State CONVRNTIONS ON THE ADOPTION OF THE FEDERAL CONSTTTUtion 480 (J. Elliot ed. 1836).

27. United States v. Burr, 25 IF. Cas. 55, 165 (No. 14,693) (C.C. Va. 1807). See also Pierson v. Ray, 386 U.S. 547, 554-55 (1967).

28. Act of July 31, 1789, ch. 12, § 2, 1 Stat. 65, 65-66. 
tion, violated the separation of powers? There are still other confirmatory materials, but let these serve.

No mention of these historical facts is made by Rosenblum. A serious scholar is under a duty to take account of what at the very least is "discrepant" evidence,;9 indeed Professors Philip Kurland and Paul Mishkin chided the Court for its failure to do so. ${ }^{30}$ To the foregoing summary may be added a significant contribution to analysis by Professor William Van Alstyne. Starting from the fact that Article II lacks an equivalent to the necessary-and-proper clause of Article I, he states:

It would appear to be plain from this provision that insofar as some larger zone of executive privilege might by Congress be deemed appropriate and expedient for the President to have, more generous by far than what a court would regard as a minimal privilege indispensable to the performance of the President's express constitutional powers (e.g., a privilege of confidentiality respecting specific troop locations during a time of military emergency as an indispensable incident of his express power as Commander in Chief), ${ }^{31}$ the necessary-and-power clause permits Congress to provide for that more generous zone of privilege. But precisely because the Constitution expressly commits all such questions of executive convenience and expediency solely to Congress and leaves nothing to inference or implication from the silence of article II, there is no room left for any court to analogize any broadly implied power of executive privilege from article II itself. ${ }^{32}$

Apparently Rosenblum considers that United States $v$. Nixon, ${ }^{33}$ to which he devotes two and one half of his eight and one half pages, ${ }^{34}$ forecloses further debate on the constitutional roots of executive

29. H. ButTERFIELD, GEORGE III AND THE HISTORIANS 225 (rev. ed. 1959).

30. "In the face of strong, if not conclusive, evidence that 'executive privilege' is a 'myth,' as Professor Berger has asserted, the Court simply assumed its existence." Kurland, United States v. Nixon: Who Killed Cock Robin?, 22 U.C.L.A.L. Rev. 68, 74 (1974) (citation omitted). "The substantial body of scholarly learning on the subject, which includes careful historical and analytic treatments, is not considered or refuted, but simply ignored." Mishkin, Great Cases and Soft Law: A Comment on United States v. Nixon, 22 U.C.L.A.L. Rev. 76, 83-84 (1974) (citation omitted).

31. For me, the historical records teach that the Commander in Chief is merely "first General," see BERGER 63, and that the deployment of troops is under congressional control, id. at 111-16. Congress is the senior partner in war-making and it is difficult for me to conceive that the President is constitutionally empowered to withhold from Congress information as to troop deployments, particularly since George Washington was kept on a tight rein by the Continental Congress. Id. at 62.

32. Van Alstyne, A Political and Constitutional Review of United States v. Nixon, 22 U.C.L.A.L. Rev. 116, 118-19 (1974).

33. 418 U.S. 683 (1974).

34. Rosenblum 659-61. 
privilege. But what he swallows whole noted scholars have subjected to raking fire. For example, Professor Paul Mishkin stated that the Court's "Inajor pronouncements are essentially ex cathedra, its analysis of the major issues simplistic, and its doctrines supported far more by the fiat of the Justices' commissions than by the weight of either learning or reasoning." ${ }^{35}$ Chief Justice Burger's statement that presidential privilege for confidential communications is "inextricably rooted" in the separation of powers ${ }^{36}$ - a view that is without judicial precedent-recalls his own remark on a similar occasion. According to Professor Leonard Levy, the Chief Justice "reported that one of the Supreme Court Justices had. said in a seminar that the presumption of innocence is 'rooted in the Constitution' and commented, 'Well, it may be rooted there, but you cannot find it there." "37 Seasoned Court watchers consider that the opinion was stitched together in order to present the intransigent $\mathrm{Mr}$. Nixon with a unanimous decision that even he would recognize as "dcfinite,"38 that some of the "privilege" remarks may not survive the occasion. ${ }^{39}$ In the words of Professor Cox, "The future may accept them or discard them as assumptions wholly unnecessary to the decision of the case, ${ }^{40}$ and what is worse, as ipse dixits that have no historical foundation." ${ }^{11}$

Rosenblun calls on me to deal with "the 'interdependence' dimension of separation of powers stressed by Chief Justice Burger."

35. Mishkin, supra note 30, at 76. See also Kurland, supra note 30, at 73-74. Professor Cox states, "The very few directly pertinent statements by members of the Constitutional Convention assert the absence of any presidential privilege." Cox 1391. "Neither the express privilege to keep the journal secret, nor the express grant of immunity from arrest ... applies to the President. If any inference is to be drawn, it is that the President is to lave no privilege." Id. at 1395 (citations omitted).

36. 418 U.S. at 708.

37. L. LEVY, AGAINST THE LAWr 18 (1974).

38. Mishkin, supra note 30, at 86-89; Van Alstyne, supra note 32, at 122-23. In "Behind the marble, beneath the robes," N.Y. Times, Mar. 16, 1975, \& 6 (Magazine), at 15, Nina Totenberg, on the basis of "information gleaned from scores of interviews with Supreme Court clerks, friends of the Justices . . . and the Justices themselves," id. at 15 col. 4, recounts of United States v. Nixon, that "when Burger circulated his first opinion draft, it met with a wholly negative response . . . . By a process of erosion [the other Justices] fimally got Burger to incorporate their language. The section that Burger is reported to have held to inost strenuously and successfully, acknowledges for the first tinie that there is a presumption of executive privilege in the Constitution." Id. at 67, col. 1-2.

39. Kurland, supra note 30 , at 74.

40. Cox 1418-19.

41. Id. at 1435; see Kurland, supra note 30, at 73-74; Mishkin, supra note 30, at 76, 83-84; cf. Van Alstyne, supra note 32, at 117, 119.

42. Rosenblum 661. 
The Chief Justice invoked Justice Jackson's dictum in Youngstown Sheet \& Tube Co. v. Sawyer: ${ }^{43}$

While the Constitution diffuses power the better to secure liberty, it also contemplates that practice will integrate the dispersed powers into a workable government. It enjoms upon its branches separateness but interdependence, autonoiny but reciprocity. ${ }^{44}$

"Reciprocity," however, is not the same as forcible entry. In "rooting" a presidential privilege for "confidential communications" in the separation of powers, Chief Justice Burger derived it "from the suprenacy of each branch" within its own sphere, and related it "to the effective discharge" of executive power. ${ }^{45}$ On these premises the privilege should be inviolable.

But Chief Justice Burger proceeded to tear a breach in that inviolability in order to prevent the privilege from impairing the courts' "fair administration of . . . justice" in a criminal case. ${ }^{46}$ That, however, was not Jackson's course. Notwithstanding his "workable government" dictum, both Justice Jackson and the Court rejected President Truman's seizure of the steel mills on the ground that it ran counter to the implicit policy of Congress. ${ }^{47}$ In other words, the needs of a "workable government" did not sanction a presidential invasion of the powers of Congress. Undeniably the Constitution "blended" certain powers. But it does not follow that the Court has a roving commission to do additional blending in the interests of a "workable government." On the contrary, Chief Justice Taft held that the "branches should be kept separate in all cases in which they were not expressly blended, and the Constitution should be expounded to blend then no nore than it affirmatively requires." 48 In this he nierely restated what Madison had nore forcefully expressed. ${ }^{49}$ This

43. 343 U.S. 579 (1952).

44. 418 U.S. at 707, quoting Youngstown Sheet \& Tube Co. v. Sawyer, 343 U.S. 579,635 (1952) (concurring opinion).

45. 418 U.S. at $708,705,711$.

46. Id. at 711-13.

47. Justice Jackson stated that the seizure was unwarranted because Congress "has covered [the twilight zone] by three statutory policies inconsistent with this seizure." 343 U.S. at 639.

48. Myers v. United States, 272 U.S. 52, 116 (1926).

49. In his discussion of "blending" in The Federarist No. 48, at 321 (Mod. Lib. 1937), Madison stated:

It is equally evident, that neither of [the departments] ought to possess, directly or indirectly, an overruling influence over the others, in the administration of their respective powers. It will not be denied, that power is of encroaching nature, and that it ought to be effectually restrained from passing the limits assigned to it.

And he emphasized the need "to provide some practical security for each, against the 
is only one of the constitutional problems that arise from and call for a reexamination of Chief Justice Burger's assumptions. ${ }^{50}$

When Rosenblum cites the Court's "acknowledgment . . . that there can be 'an absolute, unqualified ... immunity fron judicial process' under some or even many circumstances," fers to the unfortunate credence it lent to an earlier dictum in United States $v$. Reynolds, ${ }^{52}$ a private litigant case, a dictum that excluded even in camera inspection given a "claim of need to protect military, diplomatic or sensitive national security secrets." ${ }^{\text {33 }}$ Professor William Van Alstyne commented, "The reiteration from Reynolds was unnecessary . . . . Iromically, it may even imply that Mr. Nixon would have prevailed in the case had he once again mcanted the magical words 'national security." "54 Better guidance is furnisled by another statement im Reynolds: "Judicial control over the evidence in a case cannot be abdicated to the caprice of executive officers." ${ }^{\text {55 }}$ For throughout the government, the bureaucracy has an imcurable infatuation with secrecy.

Throughout I separated the constitutional from the practical arguments; first I demonstrated that executive privilege has no constitutional warrant; then I went on to show that it should also be rejected on

invasion of the others." In the words of Judge Learned Hand, judicial review "should be confined to occasions when the statute or order was outside the grant of power to the grantee, and should not include a review of how the power has been exercised." It is important, he stressed, "that within its prescribed borders each 'Department' . . . shall be free from interference." L. HAND, The BILL OF RIGHTS 31, 66 (1962). See also The Sinking Fund Cases, 99 U.S. 700, 718 (1878).

50. These and other problems are discussed in Berger, Congressional Subpoenas to Executive Officials, 75 Colum. L. REv. - (1975); Berger, The Incarnation of Executive Privilege, 22 U.C.L.A.L. Rev. 4 (1974).

Denial of demonstrably relevant evidence in reliance on doctor-patient, lawyerclient privileges might equally be deemed to "cut deeply into the guarantee of due process of law," 418 U.S. at 712, yet these privileges have been left untouched. A strange spectacle: judicial constructs stand higher than a privilege said to be "rooted" in the Constitution. See Henkin, Executive Privilege: Mr. Nixon Loses But the Presidency Largely Prevails, 22 U.C.L.A.L. REv. 40, $43-44$ (1974); Kurlaud, silpra note 30, at 7374.

51. Rosenblum 659.

52. 345 U.S. $1,9-10$ (1953).

53. 418 U.S. at $706,710-11$.

54. Van Alstyne, supra note 32, at 118. He also states, "Not since Chief Justice Vinson's opinion in United States $v$. Reynolds, which drew a sharp dissent by Justices Jackson, Frankfurter, and Black, had the Court issued an oblique invitation to the President to throttle judicial review by presenting a claim of executive privilege in the cellophane wrapper of 'national security.'" Id. at 117. See also Berger, Incarnation, supra note 50, at 26-28; Freund, Foreword: On Presidential Privilege, 88 HaRv. L. Rev. 13, 32-34 (1974).

55. 345 U.S. at 9-10. 
practical grounds. Under Rosenblum's hands this goes through a remarkable transformation:

Legal norms may be generated by courts out of social or administrative practices, but judicial alchemy has not progressed (regressed may be better) to the point where transinutation of practices into legal norms is performed spontaneously. ${ }^{56}$

So fancy a notion never entered my mind. Rather, I began with estabblished "legal norms" by showing a long-standing, untrammeled power of legislative inquiry and an absence of executive objections to such inquiries or to their scope. Only then did I go on to demonstrate that the claim should also be demied on practical grounds. ${ }^{57}$ The "alchemy" is Rosenblum's, not mine.

Similar intellectual confusion is exhibited by Rosenblum's citation of my remark that the "time and place of a Normandy invasion and the like, should not be revealed to a litigant," ${ }^{58}$ as evidence that I am "no longer dismissing [executive privilege] as a myth." 59 No litigant is given a right to executive information by the Constitution;"0 it is a judicial construct designed to facilitate judicial administration. My concern was with the constitutional right of Congress to obtain executive information. Recognition that a private litigant has no constitutional right to be informed of the Normandy invasion manifestly constitutes no abandonment of iny view that executive claims of constitutional power to deny information to Congress are unfounded.

Striking an attiude of elder statesmanship, Professor Rosenbluun states:

With termination of the blatancy and flatulence of presidential "stonewalling" and with the avowal of openness and candor by President Ford, hope now abounds that there will be no necessity for further cases to confront executive intrausigence. ${ }^{61}$

Alas, Rosenblum is being betrayed by events. On March 7, 1975, it was reported that Senator Frank Church, Chairman of the Senate Se-

56. Rosenblum 655.

57. Senator Sam J. Ervin suggested that the Executive ought not to disclose "raw and unevaluated evidence," Hearings on Executive Privilege: The Withholding of Information by the Executive Before the Senate Subcomm. on Separation of Powers, 92d Cong., 1st Sess. 440 (1971). I would join his suggestion, "not on the basis of a constitutional right to withhold or because executive moral superiority better qualifies [the Executive] to judge," but as a matter of grace. BERGER 296; cf. text accompanying notes 31-32 supra.

58. Rosenblum 657, quoting BERGER 369 (emphasis added).

59. Rosenblum 657.

60. I put to one side cases where the government bases a hurtful determination upon secret evidence. BERGER 225-26. See, e.g., Greene v. McElroy, 360 U.S. 474 (1959).

61. Rosenblum 660. 
lect Committee on Intelligence, called upon President Ford to facilitate transmittal of information by federal agencies to the Committee. Mr. Ford made no commitments, and according to Senator Church,

Mr. Ford did not rule out the possibility that he might invoke "executive privilege" and order the withholding of some material and witnesses. He may have been influenced by a warning he is said to have received orally from Mr. Colby [head of Central Intelligence Agency] that the investigation could bring out highly embarrassing matters . . .".62

Here is an investigation into noisome practices that have shocked the American people and that call for exposure in the interest of thorough-going reform, and once again we are told that disclosure may prove "embarrassing." Once again executive privilege may be invoked to shield rank misdeeds. We dare not depend on the grace of a given President but must view secrecy as an occupational disease of the bureaucracy which infects all who come in contact with it.

Rosenblum also calls on me to formulate "guidelines and exainples for Congress and the judiciary to follow in differentiating privileged from nonprivileged situations." ${ }^{363}$ So far as regards congressional deinands for information, my study convinced me that there are no constitutionally "privileged" situations. The Nixon criterion was the need in a judicial case for information in the interest of the "fair administration of criminal justice." ${ }^{\text {(64 }}$ How real the need for information is necessarily a matter for case to case evaluation. The needs of Congress stand on a higher level than the needs of an individual accused of crime. Whether the public interest at stake be in the impeachment of a high officer or in congressional investigations such as Watergate and Teapot Doine under the congressional "oversight" power, Congress too can maintain that a claim of privilege cannot be permitted to "impair" its functions. ${ }^{65}$ Who is to be the judge of such impairment? In a forthcoming article, I conclude that except on the issues of jurisdiction and relevance to the inquiry, the decision is for Congress. ${ }^{\circ 0}$ Recent developments have led Professor Archibald Cox to conclude that it is

62. N.Y. Times, Mar. 9, 1975, § 4, at 1, col. 3; cf. N.Y. Times, Mar. 16, 1975, $\S 4$, at 4, col. 2. See also N.Y. Times, March 10, 1975, at 49, col. 2.

63. Rosenblum 658-59. Some of such questions I have treated elsewhere; see note 50 supra.

64. 418 U.S. at 711-13.

65. See Berger, Incarnation, supra note 50, at 9-10; Cox 1436-38; Henkiu, supra note 50 , at 43 .

66. Berger, Congressional Subpoenas, supra note 50. 
desirable to put the force of law behind some congressional subpoenas addressed to the President, his aides or other executive officials. Ideally, I think, the legislative right should prevail in every case in which either the Senate or House of Representatives votes to override the Executive's objections,

subject to jurisdiction and relevance to the inquiry. ${ }^{87}$

We should not take our leave of Professor Rosenblum without comment on his "Of special interest to the Northwestern community is NU alum [sic] Berger's disagreement at one point with Dean Wigmore." 68 The reference is to Wigmore's citation to a statement by Chief Justice Marshall in United States v. Burr, as to which Berger said Wigmore "is plainly mistaken."

Says Rosenblun, "Wigmore might, at soine point, be fallible (though no Northwestern grad e'er found him so); Berger's gossamer analysis of the Burr case, however, hardly provides a foundation for challenge to the mighty Dean." B9 Before turning to my "gossamer analysis," it is not inappropriate to remark on Rosenblum's embarrassing appeal to stuffy parochialism. Northwestern "grads," like all lawyers, are given to questioning all authority; in the legal lexicon there are no sacred cows. ${ }^{70}$

Now for the merits. The dispute, to quote Rosenblum, centers on

Marshall's sentence, "[i]f it contain matter not essential to the defense, and the disclosure be unpleasant to the executive, it certainly ought not to be disclosed." Berger stressed "if" and "not essential to the defense," downgrading the significance of "unpleasantness" of the disclosure to the executive as a coordinate factor in determining privilege. That a nuance of emphasis in verbal analysis about which reasonable people might differ would warrant the conclusion that Wigmore was "plainly mistaken" in his construction requires immersion in the evaluation world of Alice-in-Wonderland. ${ }^{71}$

I should have thought it plain that the negative pregnant is that "if" "unpleasant" disclosure be "essential to the defense" it "certainly ought . . . to be disclosed." Were this a doubtful "nuance," several other statements by Marshall make clear that if the defendant made a strong

67. Cox 1434 (emphasis added).

68. Rosenblum 656.

69. Id. at 657.

70. Referring to The Federalist, Chief Justice Marshall said, "No tribute can be paid to [its authors] which exceeds their merit; but in applying their opinions to the cases which may arise in the progress of our government, a right to judge of their correctness must be retained . . . " McCulloch v. Maryland, 17 U.S. (4 Wheat.) 316, 433 (1819).

71. Rosenblum 657 (emphasis added). 
showing of need for a document, "production would be insisted on" notwithstanding the presidential representation that it was "improper to exhibit it in public."'72 After his own study of the Burr case, Professor Paul Freund recently concluded that it established the principle, among others, that "[u]pon a particularized claim of privilege by the President the court, giving due respect to the President's judgment, will weigh the claim against the materiality of the evidence and the need . . . for its production," and if such need be found, the court will order production. ${ }^{73}$ Following in this path, United States v. Nixon held that given the Special Prosecutor's need for the "White House tapes," President Nixon had to deliver them, "confidentiality" notwithstanding. ${ }^{74}$ These materials demonstrate that it is Rosenblum who has engaged in "gossamer analysis."

Since he writes so cosily within the "Northwestern community," it inay not be amiss to remimd him that I borrowed my subtitle "A Constitutional Myth" from one of the most distinguished NW alumni, George Ball, ${ }^{75}$ and that another illustrious alumnus, former Justice Arthur J. Goldberg wrote, "Professor Berger's book is an honest presentation . . . . On the basis of ny own study of this doctrime, I am in substantial agreement with Professor Berger."76

When I entered law practice forty years ago, George Haight, an eminent Chicago lawyer, told me that what makes a fine lawyer is "lots of scar tissue." The weight of more scars than Professor Rosenblum has yet had time to accumulate impels me to trade sage counsels with him-more hard-headed analysis and less inflated rhetoric.

72. United States v. Burr, 25 F. Cas. $187,191-92$ (No. 14, 694) (C.C. Va. 1807); see Berger 190-91.

73. Freund, supra note 54, at 31. See also Berger, The President, Congress, and the Courts, 83 Y ALE L.J. 1111, 1111-22 (1974).

74. 418 U.S. at 713.

75. Ball referred to "the myth of Executive privilege, and it is indeed a myth, for I find no constitutional basis for it ...." Hearings on War Powers Legislation Before the Senate Comm. on Foreign Relations, 92d Cong., 1st Sess. 626, quoted in BERGER $1 \mathrm{n} .2$.

76. Goldberg, Book Review, Christian Sci. Monitor, May 15, 1974, § F, at 5, col. 3. 